\title{
閉鎖空間内にある材料の非接触 測色法の提案
}

\section{PROPOSAL OF NON-CONTACT COLORIMETRIC MEASUREMENT OF MATERIALS IN A CLOSED SPACE}

\author{
磯見麻衣 — $* 1$ 酒井英樹 — $* 2$ \\ 伊與田浩志—— $* 3$ \\ キーワード : \\ 測色，閉鎖空間，照射・受光条件，デジタルカメラ
}

Keywords:

Colorimetry, Closed space, Incident / receiving geometries, Digital camera

$\begin{array}{lll}\text { Mai ISOMI- Hideki SAKAI- } & * 1 \\ \text { Hiroyuki IYOTA } & * 3\end{array}$

It was shown that the color of materials in a closed space can be measured from the outside of space under diffuse illuminations by using a concave glass as a partition. The measurement accuracy is $\Delta E^{*}{ }_{a b}=$ 0.9 in average for 24 colors of the standard color chart, where $\Delta E_{a b}^{*}$ is the color difference in $L^{*} a^{*} b^{*}$ (D65/ 2-deg.) color space of JIS Z87814. It is lower than that of the conventional colorimetry without a glass partition, in which the measurement accuracy is $\Delta E^{*}{ }_{a b}=0.7$ in average; it is, however, high enough compared to that of visual colorimetry.

\section{1.はじめに}

本研究では, 外気から遮断された空間内にある材料を, その外側 から非接触で測色する方法を提案する。これは, 温度・湿度が材料 に与える影響 ${ }^{1)}$ を調べる際に, 調温・調湿された容器内に材料を置 き, 透明ガラス空を通して容器外から測色することや, 歴史的に価 值のある文化財の外観検查やデジタルアーカイブ 2)を，外気に触れ て劣化させないように, 保存容器から取り出さずに行うことを念頭 においたものである。

ここで，材料を測色するには，光を照射し，その材料表面で反射 された光を受光する必要がある。そして, その際の照射・受光条件 は, Fig. 1 に示寸 (a) 45 度入射 /垂直受光（又は, 垂直入射 $/ 45$ 度受光）と（b）拡散入射／垂直受光（又は，垂直入射／拡散受光） とが日本産業規格 JIS Z 8722 3,4) で定められており, 状況に応じて, どちらかを選択して測色することが求められる。

閉ざされた空間内にある材料を測色するには, 透明ガラスを通し て光を照射することになるが, 高光沢である透明ガラス表面では, 照射した光の一部が正反射される。しかし, この正反射光は, 材料 の色とは無関係である。よって, 測色する際は, この正反射光を避

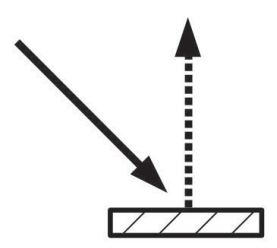

(a) $45^{\circ} /$ normal

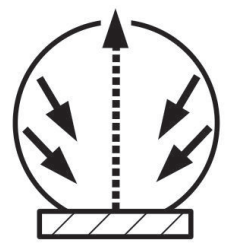

(b) diffuse / normal
Fig. 1 The incident / receiving geometries defined by JIS Z 8722
けて, 材料表面からの反射光だけを受光する必要があるが, 正反射 光は入射角と反射角が等しい, という性質があるため, Fig. 2 (a) に 示すように，45 度入射／垂直受光であれば，ガラス表面の正反射光 が受光されることはない。対して, Fig. 2（b）に示寸拡散入射／垂 直受光では, 一部の正反射光が受光される。つまり, ガラス表面に 照射光源が映り込み, 材料表面の反射光の測定を妨害してしまう。 そこで, 閉鎖空間内の材料の測色を行うには, 45 度入射／垂直受光 が適している5 ${ }^{5}$ 。

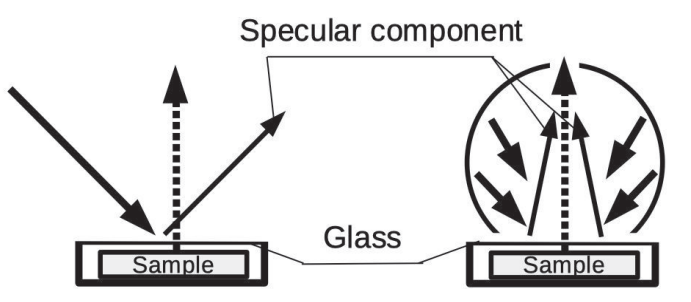

(a) $45^{\circ} /$ normal

(b) diffuse / normal

Fig. 2 The incident / receiving geometries through glass plate

ところが，45 度入射／垂直受光の条件では, 平らな材料であれば 問題なく測色できるが，凹凸のある材料の場合，1つの入射角（45 度）からの照射では, 凹凸による陰影が発生しやすく, その場合, 正しく測色できない。そこで, 通常であれば, 拡散入射／垂直受光, つまり, あらゆる入射角・方位角から光を照射し, 陰影を発生させ ずに測色することが可能だが，上述の通り，ガラスを隔てた測色で は，それができない。

そこで, 本研究では, この問題の解決策として, 空間を隔てるガ

\footnotetext{
大阪市立大学大学院生活科学研究科 大学院生・修士（学術

( T558-8585 大阪市住吉区杉本 3-3-138)

大阪市立大学大学院生活科学研究科 教授・博士 (理学)

大阪市立大学大学院工学研究科 教授・博士 (工学)
}

\footnotetext{
Graduate Student, Graduate School of Human Life Science, Osaka City Univ., M.A.

Prof., Graduate School of Human Life Science, Osaka City Univ., Dr.Sci.

Prof., Graduate School of Engineering, Osaka City Univ., Dr.Eng.
} 
ラスを凹状にすることで，拡散入射光を垂直方向以外に正反射させ， ガラス表面への光源の映り込みを抑制する方法を提案する。以下， 本手法の妥当性を, 理論的に検討したのち, 実際に, 凹状ガラスで 空間を閉鎖し，その中に置かれた凹凸のある材料を測色した結果を 報告する。

\section{2. 理論}

実験に先立ち, Fig. 2(b) 拡散入射／垂直受光において, 空間を隔 てるガラスがどのような形状であれば，ガラス表面への光源の映り 込みを抑制することができるかを, 光線軌跡を可視化できる光学シ ミュレーションソフト OpticalRayTracer ${ }^{6)}$ を用いて検討した。まず, 測定試料を封入する容器として直径 $100 \mathrm{~mm}$, 高さ $20 \mathrm{~mm}$ の円筒形シ ヤーレを仮定し, その容器全体を照射するための積分球（内壁に無 光沢の白色塗料が塗布された球体で内部に均一な拡散光を生成する 光学部品）として, 直径 $300 \mathrm{~mm}$ の半球体を仮定した。また, 受光方 法については, 容器の垂直上方となる積分球の天頂部分に直径 $30 \mathrm{~mm}$ の観察口があり, さらにその上方 $50 \mathrm{~mm}$ の位置に受光器（カメラ） がある，と仮定した。

以上の条件で, 容器の蓋のガラス形状として, (a) 平面状, (b) 曲 率半径 $200 \mathrm{~mm}$ の凹状の場合について, 仮想的に受光器の位置に点光 源を置き, 光線がガラス表面で正反射される様子を計算した。なお, 曲率半径 $200 \mathrm{~mm}$ は, 凹状ガラスからの正反射光の焦点が受光器の位 置付近となるように設定した。その結果, Fig. 3 に示寸通り, (a) 平 面状では一部の光線が積分球内壁に到達した。これは, 受光器の位 置から観察した場合, 積分球内壁がガラス表面に映り込むことを意 味する。一方，（b）凹状では全ての光線が受光器の位置に戻った。 しかし, 実際には受光器からは光は出ないので, ガラスには映るこ とはない。よって, ガラスはあたかも存在していないかのごとく, 容器内の試料からの反射光だけが受光器に届くことになる。

以上, 光学シミュレーションにより, 空間を隔てるガラスを, 受 光器を焦点とする曲率を持った凹状とすることで, ガラス表面への 照射光源の映り込みが抑制できることを確認した。

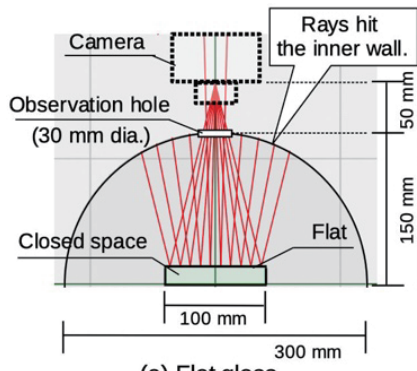

(a) Flat glass

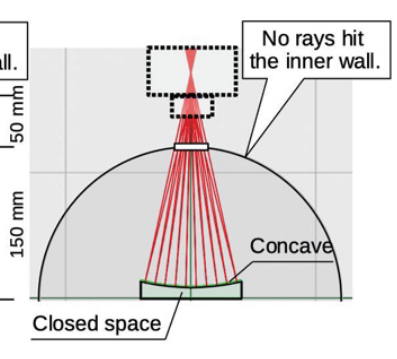

(b) Concave glass
Fig. 3 Specular-component ray trajectories of virtual point source at camera

\section{3. 実験方法}

\section{1 装置}

2 章の理論に基づいて設計した閉ざされた空間内にある試料を測 色する装置（断面図）をFig. 4 亿示す。拡散光を生成する積分球と して, 直径 $300 \mathrm{~mm}$ のアクリル樹脂製の球体の内壁を白色塗料で塗布 したものを作製し, LED ランプで積分球中心照度が 2,000 1x になる
ように調光した。積分球の形状は半球であるが, その底面部分に反 射鏡を設置することで，下半球面を鏡像と寸る積分球としている。 そして, テープ状の高演色白色 LED ランプ (相関色温度 $6,200 \mathrm{~K}$, 平 均演色評価数 $\mathrm{Ra}=90$ ）を底面周囲の内壁を一周するように配し, LED からの直接光が試料に照射されないように障壁を設置することで, 均一な拡散光照明を実現した ${ }^{7)}$ 。次に, 容器として, 底面中央に, 直径 $91 \mathrm{~mm}$, 高さ $21 \mathrm{~mm}$ のソーダ石灰ガラス製シャーレを設置し, その中に色補正用の標準色票と測定試料を入れた。また, 外気から 遮断された空間を作るための蓋には, 同じくソーダ石灰ガラス製の 直径 $106 \mathrm{~mm}$, ガラス厚み $2 \mathrm{~mm}$, 曲率半径 $200 \mathrm{~mm}$ の時計血を用いた。 さらに比較用に, ソーダ石灰ガラス製の直径 $96 \mathrm{~mm}$, ガラス厚み $2 \mathrm{~mm}$ の平面ガラスも蓋として用いた注 ${ }^{1)}$ 。そして, 受光器には, 一眼レフ デジタルカメラ Nikon D5100（ズームレンズ AF-S NIKKOR 18-55mm F3. 5-5. 6 G II ED を焦点距離 $55 \mathrm{~mm}$ に固定し使用）を用いて, 積分球 の天頂部の直径 $30 \mathrm{~mm}$ の観察口の上方 $50 \mathrm{~mm}$ に設置した。そして, 撮影は, 被写界深度 ${ }^{7)}$ が最大となるように絞り值をレンズ上限の F36. 0 とし, 適正露出となるシャッター速度 $1 / 1.3$ 秒で RAW 撮影 (4928×3264 画素) した後, 画像サイズを半分に縮小し, 非圧縮の TIFF 形式 $(2464 \times 1632$ 画素) に変換した。変換後の撮影画像の 21.72 画素が， $1.0 \mathrm{~mm}$ に相当する。

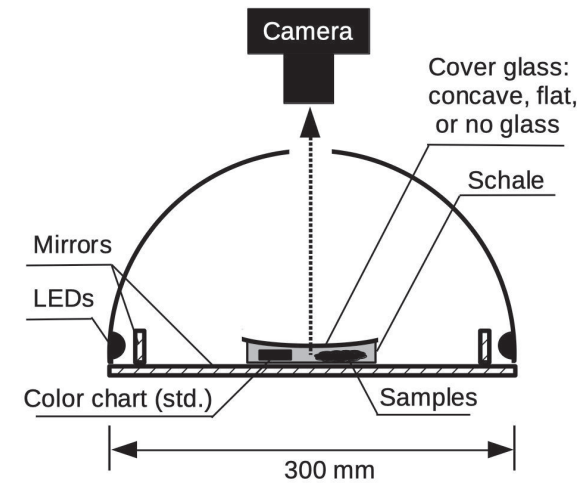

Fig. 4 Setup of hemi-spherical diffuse illumination

ここで, デジタルカメラは, 測色器として市販されているもので はない。しかし, 均一な照明の下で撮影し, 適切に色補正を行えば, 高解像度の測色画像が色彩計と同程度の精度で得られることから, 近年, 色分布の測定 (2 次元測色) に広く使われている ${ }^{8,9)}$ 。色補 正の方法はいくつかあるが ${ }^{4}$, 本研究では, 伊與田ら ${ }^{10)}$ の画像処理 方法として，シェーディング補正（明るさ補正）とRGB 色補正の 2 段階補正を採用した。

まず, シェーディング補正として, 試料の代わりに, 無光沢白色 紙を撮影し，その撮影画像の RGB 值から，ガラスを透過することに よる照明の不均一性（ガラスがある場合）や, 色温度, レンズの周 辺光量の減衰を原因とする明るさの不均一さを補正するための係数 を画素ごとに算出する。そして, これ以降撮影した画像には, す心゙ て補正係数を画素ごとに掛けることで，均一な明るさの照明光の下 で撮影された画像となる補正を行う。(シェーディング補正の計算式 は, 文献 10 の 2.2.1 節を参照のこと。)

次に RGB 色補正として, 試料を撮影する際は, Fig. 4 に示すよう に, 試料横に標準色票 (Image Science 社の色補正用色票 ColorGauge 
Nano 注2) を置いて撮影し, シェーディング補正を行った後, 画像内 の標準色票 24 色が, 色票の規格 RGB 值になるように画像全体を色補 正する。(RGB 色補正の計算式は, 文献 10 の 2.2.2 節を参照のこと。)

このようにして得られる補正後の画像は, 各画素の RGB 值が測色 值 SRGB となっており, 各種表色系に変換可能であるが, 本研究では これをJIS X9204 ${ }^{11)}$ に基づいて色の三刺激值 XYZに変換し,さらに, JIS Z8781-4 ${ }^{12)}$ の変換式を使って, $L^{*} a^{*} b^{*}$ 值（D65 光/ $2^{\circ}$ 視野）に変 換した。色表示として D65 光と $2^{\circ}$ 視野を採用した理由は, 今回使 用した色補正用色票が，その条件で規格化されているためである。 また, $L^{*} a^{*} b^{*}$ 表色系を採用した理由は, 色差式が簡便であり, 測色精 度の議論がしやすいためである。これら色の表示方法は, 本研究で 提案する閉鎖空間内の非接触測色法の必須条件ではなく, 必要に応 じて自由に選択することができる。

\section{2 測定条件・試料}

本研究では次の 3 通りの条件で測色を行った。条件 1 は蓋のない 開放条件, 条件 2 は平面状ガラスで蓋をした従来の閉鎖条件 (以下, 平面ガラス閉鎖条件), 条件 3 は本研究で提案する凹状ガラスで蓋を した閉鎖条件（以下，凹状ガラス閉鎖条件）で，それぞれ測色精度 を検証するために，色補正に用いた標準色票と同じ色票をもう $1 つ$ 用意し，それを試料として測定した。Fig. 5 が実際に撮影した画像 の例（条件 1, 色補正後）であり, 試料として測定した Fig. 5 右の 色票 24 色それぞれについて, 直径 $1.5 \mathrm{~mm}$ の円内に含まれる 1,009 画素（白抜き箇所）の平均 $L^{*} a^{*} b^{*}$ 值を算出し, 標準色票 24 色の基準 值（standard，std）との色差 $\Delta E^{*} a b$ を次式(1)で計算した。

$$
\Delta E_{a b}^{*}=\left\{\left(L^{*}-L_{\text {std }}^{*}\right)^{2}+\left(a^{*}-a_{\text {std }}^{*}\right)^{2}+\left(b^{*}-b_{\text {std }}^{*}\right)^{2}\right\}^{0.5}
$$

また，測定事例として，凹凸のある白色壁紙（アサヒペン・塩化 ビニル樹脂補修用カベ紙, 品番 $\mathrm{HK}-15)$ と同じく凹凸のある灰色塗 膜 (アサヒペン・黒色ストーン調塗料に, ニッペホームプロダクッ・ ダークグレー合成樹脂塗料を重亦叙りしたもの)を 3 片ずつ用意し, 測色を行った。そして, 接触式色彩計コニカミノルタ CM-2600d（拡 散入射 /垂直受光, $D 65$ 光 $/ 2^{\circ}$ 視野, 測定径 $8 \mathrm{~mm}$ ) で測色した值と 比較した。

\section{4. 結果及び考察}

\section{1 開放条件 (条件 1)}

Table 1 に蓋のない開放条件で, 試料として測定した色票 24 色の

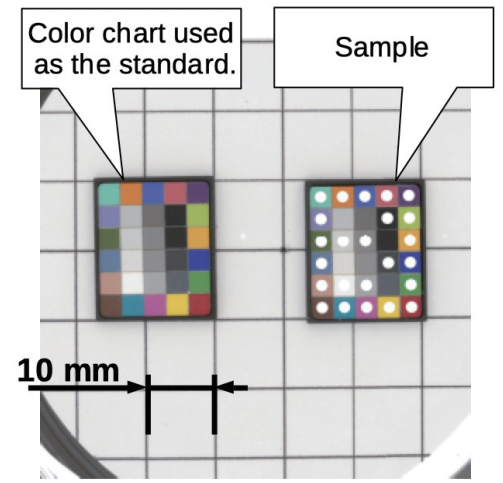

Fig. 5 Example of color-corrected image of condition 1 (no glass)
Table 1 Results of measurement accuracy of condition 1 (no glass)

\begin{tabular}{|c|c|c|c|c|c|c|c|c|}
\hline \multicolumn{5}{|c|}{ ColorGauge 24 colors $L^{*} a^{*} b^{*}$ values } & \multicolumn{3}{|c|}{ Results with no glass } & \multirow{2}{*}{$\begin{array}{l}\text { Color diff. } \\
\Delta E^{*} a b, n o\end{array}$} \\
\hline No. & color name & $L^{*}$ std & $a^{*} \operatorname{std}$ & $b^{*}$ std & $L^{*}$ no & $a^{*}$ no & $b^{*}$ no & \\
\hline 1 & dark skin & 38.0 & 11.8 & 13.7 & 38.0 & 12.3 & 13.3 & 0.7 \\
\hline 2 & light skin & 65.7 & 13.7 & 16.9 & 65.5 & 14.1 & 16.8 & 0.5 \\
\hline 3 & blue sky & 50.6 & 0.4 & -21.6 & 50.5 & 0.5 & -21.8 & 0.2 \\
\hline 4 & foliage & 43.0 & -15.9 & 20.5 & 43.4 & -16.1 & 21.5 & 1.1 \\
\hline 5 & blue flower & 55.7 & 12.8 & -25.2 & 55.7 & 12.8 & -25.0 & 0.1 \\
\hline 6 & bluish green & 71.0 & -30.6 & 1.5 & 70.8 & -30.3 & 1.4 & 0.5 \\
\hline 7 & orange & 61.1 & 28.1 & 56.1 & 61.0 & 29.2 & 55.5 & 1.3 \\
\hline 8 & purplish blue & 41.1 & 17.4 & -41.9 & 41.1 & 17.6 & -42.3 & 0.4 \\
\hline 9 & moderate red & 51.3 & 42.1 & 14.9 & 51.0 & 42.3 & 15.0 & 0.3 \\
\hline 10 & purple & 31.1 & 24.4 & -22.1 & 31.0 & 24.5 & -22.7 & 0.6 \\
\hline 11 & yellow green & 71.9 & -28.1 & 57.0 & 72.6 & -27.6 & 58.0 & 1.3 \\
\hline 12 & orange yellow & 71.0 & 12.6 & 64.9 & 71.1 & 12.2 & 65.8 & 1.0 \\
\hline 13 & blue & 30.4 & 26.4 & -49.7 & 29.7 & 26.7 & -50.4 & 1.0 \\
\hline 14 & green & 55.0 & -40.1 & 32.3 & 55.1 & -40.6 & 32.7 & 0.6 \\
\hline 15 & red & 41.3 & 49.3 & 24.7 & 40.7 & 48.9 & 25.3 & 1.0 \\
\hline 16 & yellow & 80.7 & -3.7 & 77.6 & 80.3 & -3.8 & 77.2 & 0.5 \\
\hline 17 & magenta & 51.1 & 48.2 & -15.3 & 51.1 & 47.4 & -15.8 & 0.9 \\
\hline 18 & cyan & 51.2 & -19.7 & -23.4 & 51.6 & -19.7 & -23.1 & 0.5 \\
\hline 19 & white(N9.5) & 95.8 & -0.2 & 0.5 & 95.1 & -0.1 & 0.5 & 0.7 \\
\hline 20 & $\mathrm{~N} 8.2$ & 82.8 & 0.0 & 0.0 & 82.9 & 0.0 & 0.3 & 0.3 \\
\hline 21 & N6.8 & 69.2 & 0.0 & 0.0 & 69.0 & -0.2 & 0.0 & 0.3 \\
\hline 22 & N5.5 & 55.9 & 0.0 & 0.0 & 55.8 & -0.1 & 0.4 & 0.5 \\
\hline 23 & N3.1 & 31.5 & 0.0 & 0.0 & 31.1 & 0.1 & -0.3 & 0.4 \\
\hline 24 & black(N2.1) & 21.7 & 0.0 & 0.0 & 20.9 & 0.0 & 0.0 & 0.8 \\
\hline & & & & & & & Max. & 1.3 \\
\hline & & & & & & & Min. & 0.1 \\
\hline & & & & & & & Ave. & 0.7 \\
\hline
\end{tabular}

測色値 $L^{*}$ no, $a^{*}$ no, $b^{*}$ no と, 標準色票の基準值との色差 $\Delta E^{*} a b$, no を 示す。色差の最大は No. 7 橙 (orange) と No. 11 黄緑（yellow green） の 1.3 で, 他の色はほぼ 1.0 以下に収まっており, 24 色の平均色差 は 0.7 であった。このように基準值からの色差は非常に小さく, 本 実験の色補正が正しく行われていることが確認できた。

\section{2 平面ガラス閉鎖条件（条件 2)}

次に, Table 2 に平面ガラスで蓋をした閉鎖条件での色票 24 色の 測色值 $L^{*} \mathrm{f} 1, a^{*} \mathrm{fl}, b^{*} \mathrm{fl}$ と, 標準色票の基準值との色差 $\Delta E^{*} a b, \mathrm{fl}$ を示す。Fig. 3 (a) の光学シミュレーション結果の通り, この条件 では, ガラス面で正反射された積分球内壁からの照射光が, 試料面 からの反射光に混入する。基準值との色差は 24 色の平均では 2.8 であるが, No. 3 空色 (blue sky) と No. 4 葉色（foliage）では色差 が 10 を超えており, 正しく色補正されていない。よって, 拡散入射 による平面ガラスを通しての材料の高精度の測色は困難であること がわかる。

\section{3 凹状ガラス閉鎖条件（条件 3)}

次に, Table 3 に本研究で提案する凹状ガラスで蓋をした閉鎖条 件での色票 24 色の測色值 $L^{*}{ }^{*}$ wa $a^{*}$ wa， $b^{*}$ wa と, 標準色票の基準值と の色差 $\Delta E^{*} a b$, wa を示す。No. 14 緑 (green) が 2. 3, No. 24 黒 (black) が 2.2 となり，色差 2 を超えたが，他の色はほぼ 1.0 程度に収まっ ており, 24 色の平均色差は 0.9 であった。このように, 開放条件 (条 件 1）と比べると, 色差が大きくなるものの, 色差 2 程度の精度は 期待できることが確認できた。よって, 本測色法を, 従来困難であ った閉ざされた空間内の材料を, その外側から測色する方法として 提案する。 
Table 2 Results of measurement accuracy of condition 2 (flat glass)

\begin{tabular}{|c|c|c|c|c|c|c|c|c|}
\hline \multicolumn{5}{|c|}{ ColorGauge 24 colors $L^{*} a^{*} b^{*}$ values } & \multicolumn{3}{|c|}{ Results with flat glass } & \multirow{2}{*}{$\begin{array}{l}\text { Color diff. } \\
\triangle E^{*} a b, \mathrm{fl}\end{array}$} \\
\hline No. & color name & $L^{*}$ std & $a^{*}$ std & $b^{*} \operatorname{std}$ & $L^{*} \mathrm{fl}$ & $a^{*} \mathrm{fl}$ & $b^{*} \mathrm{fl}$ & \\
\hline 1 & dark skin & 38.0 & 11.8 & 13.7 & 36.7 & 10.7 & 14.3 & 1.8 \\
\hline 2 & light skin & 65.7 & 13.7 & 16.9 & 65.0 & 16.1 & 16.6 & 2.5 \\
\hline 3 & blue sky & 50.6 & 0.4 & -21.6 & 40.3 & -0.7 & -27.7 & 12.0 \\
\hline 4 & foliage & 43.0 & -15.9 & 20.5 & 29.3 & -18.7 & 28.3 & 16.0 \\
\hline 5 & blue flower & 55.7 & 12.8 & -25.2 & 52.9 & 12.7 & -25.8 & 2.8 \\
\hline 6 & bluish green & 71.0 & -30.6 & 1.5 & 70.3 & -29.5 & 1.0 & 1.4 \\
\hline 7 & orange & 61.1 & 28.1 & 56.1 & 60.9 & 28.4 & 55.8 & 0.5 \\
\hline 8 & purplish blue & 41.1 & 17.4 & -41.9 & 40.8 & 16.4 & -42.0 & 1.1 \\
\hline 9 & moderate red & 51.3 & 42.1 & 14.9 & 51.0 & 42.2 & 15.7 & 0.9 \\
\hline 10 & purple & 31.1 & 24.4 & -22.1 & 30.8 & 22.9 & -21.0 & 1.8 \\
\hline 11 & yellow green & 71.9 & -28.1 & 57.0 & 72.6 & -27.5 & 57.8 & 1.2 \\
\hline 12 & orange yellow & 71.0 & 12.6 & 64.9 & 71.4 & 9.1 & 65.5 & 3.6 \\
\hline 13 & blue & 30.4 & 26.4 & -49.7 & 33.4 & 23.1 & -45.8 & 5.9 \\
\hline 14 & green & 55.0 & -40.1 & 32.3 & 54.6 & -36.4 & 29.5 & 4.7 \\
\hline 15 & red & 41.3 & 49.3 & 24.7 & 40.6 & 48.1 & 24.2 & 1.5 \\
\hline 16 & yellow & 80.7 & -3.7 & 77.6 & 80.0 & -3.9 & 76.7 & 1.1 \\
\hline 17 & magenta & 51.1 & 48.2 & -15.3 & 50.9 & 47.1 & -14.9 & 1.2 \\
\hline 18 & cyan & 51.2 & -19.7 & -23.4 & 50.5 & -18.2 & -24.4 & 1.9 \\
\hline 19 & white(N9.5) & 95.8 & -0.2 & 0.5 & 95.1 & -0.1 & 0.6 & 0.7 \\
\hline 20 & N8.2 & 82.8 & 0.0 & 0.0 & 82.6 & 0.1 & 0.0 & 0.1 \\
\hline 21 & N6.8 & 69.2 & 0.0 & 0.0 & 68.4 & -0.1 & -0.1 & 0.8 \\
\hline 22 & N5.5 & 55.9 & 0.0 & 0.0 & 55.5 & 0.1 & -0.2 & 0.5 \\
\hline 23 & N3.1 & 31.5 & 0.0 & 0.0 & 30.2 & 1.1 & -1.1 & 2.0 \\
\hline 24 & black(N2.1) & 21.7 & 0.0 & 0.0 & 21.4 & 0.9 & -0.9 & 1.3 \\
\hline & & & & & & & Max. & 16.0 \\
\hline & & & & & & & Min. & 0.1 \\
\hline & & & & & & & Ave. & 2.8 \\
\hline
\end{tabular}

Table 3 Results of measurement accuracy of condition 3

(concave watch glass)

\begin{tabular}{|c|c|c|c|c|c|c|c|c|}
\hline \multicolumn{5}{|c|}{ ColorGauge 24 colors $L^{*} a^{*} b^{*}$ values } & \multicolumn{3}{|c|}{ Results with watch glass } & \multirow{2}{*}{$\begin{array}{l}\text { Color diff. } \\
\Delta E^{*} a b, \text { wa }\end{array}$} \\
\hline No. & color name & $L^{*}$ std & $a * \operatorname{std}$ & $b^{*} \mathrm{std}$ & $L^{*} w a$ & $a^{*}$ wa & $b^{*}$ wa & \\
\hline 1 & dark skin & 38.0 & 11.8 & 13.7 & 37.6 & 12.0 & 13.1 & 0.7 \\
\hline 2 & light skin & 65.7 & 13.7 & 16.9 & 65.4 & 14.2 & 16.7 & 0.6 \\
\hline 3 & blue sky & 50.6 & 0.4 & -21.6 & 50.4 & 0.3 & -21.5 & 0.3 \\
\hline 4 & foliage & 43.0 & -15.9 & 20.5 & 43.2 & -16.3 & 21.2 & 0.9 \\
\hline 5 & blue flower & 55.7 & 12.8 & -25.2 & 55.4 & 13.1 & -25.3 & 0.4 \\
\hline 6 & bluish green & 71.0 & -30.6 & 1.5 & 70.7 & -30.3 & 1.2 & 0.5 \\
\hline 7 & orange & 61.1 & 28.1 & 56.1 & 60.7 & 29.6 & 55.5 & 1.6 \\
\hline 8 & purplish blue & 41.1 & 17.4 & -41.9 & 40.6 & 17.6 & -42.6 & 0.9 \\
\hline 9 & moderate red & 51.3 & 42.1 & 14.9 & 50.9 & 42.7 & 14.9 & 0.7 \\
\hline 10 & purple & 31.1 & 24.4 & -22.1 & 31.0 & 24.0 & -22.1 & 0.4 \\
\hline 11 & yellow green & 71.9 & -28.1 & 57.0 & 72.4 & -27.5 & 57.9 & 1.2 \\
\hline 12 & orange yellow & 71.0 & 12.6 & 64.9 & 71.1 & 12.3 & 65.5 & 0.7 \\
\hline 13 & blue & 30.4 & 26.4 & -49.7 & 29.0 & 26.2 & -50.3 & 1.5 \\
\hline 14 & green & 55.0 & -40.1 & 32.3 & 54.0 & -41.7 & 33.6 & 2.3 \\
\hline 15 & red & 41.3 & 49.3 & 24.7 & 40.1 & 48.5 & 25.6 & 1.7 \\
\hline 16 & yellow & 80.7 & -3.7 & 77.6 & 80.2 & -3.9 & 76.9 & 0.9 \\
\hline 17 & magenta & 51.1 & 48.2 & -15.3 & 50.8 & 47.3 & -15.8 & 1.0 \\
\hline 18 & cyan & 51.2 & -19.7 & -23.4 & 51.3 & -19.8 & -23.2 & 0.2 \\
\hline 19 & white(N9.5) & 95.8 & -0.2 & 0.5 & 95.2 & -0.1 & 0.5 & 0.7 \\
\hline 20 & N8.2 & 82.8 & 0.0 & 0.0 & 82.7 & 0.1 & -0.1 & 0.1 \\
\hline 21 & N6.8 & 69.2 & 0.0 & 0.0 & 68.9 & -0.5 & 0.0 & 0.6 \\
\hline 22 & N5.5 & 55.9 & 0.0 & 0.0 & 55.8 & -0.1 & 0.6 & 0.7 \\
\hline 23 & N3.1 & 31.5 & 0.0 & 0.0 & 30.6 & -0.3 & -0.1 & 0.9 \\
\hline 24 & black(N2.1) & 21.7 & 0.0 & 0.0 & 19.5 & -0.2 & 0.0 & 2.2 \\
\hline & & & & & & & Max. & 2.3 \\
\hline & & & & & & & Min. & 0.1 \\
\hline & & & & & & & Ave. & 0.9 \\
\hline
\end{tabular}

なお，開放条件と比べて色差がわずかに大きくなった原因として は, Table 3 より, 基準值との色差が大きい色票は, $L^{*}$ 值が 1 程度 低く測定される傾向があることから, 凹状ガラス（透過率 0.93 , 実 測值）を透過することで照射光，反射光とも開放条件よりも目減り した影響や，相対的にノイズが増加したことなどが考えられる。よ って, 照射光の光量を増強する, 凹状ガラスを薄くする, 透過率の 高い石英ガラス製にする, 反射防止コーティングを施す, などする ことで，測定精度が改善する可能性がある。

\section{5. 測定事例}

最後に, 実際の材料を使った検証として, 条件 1 の開放条件と条 件 3 の凹状ガラス閉鎖条件とで, 白色壁紙と灰色塗膜を測色し, 市 販の接触式色彩計で測色した結果と比較した。3.2 節の説明の通り, これらの材料表面には凹凸があり, 45 度入射／垂直受光では, 材料 本来の色が測定できない試料である。

Fig. 6 に条件 3 で撮影した際の色補正後の画像例を示す。壁紙, 塗膜とも $20 \mathrm{~mm} \times 30 \mathrm{~mm}$ の大きさで, それぞれ 3 片用意し, 壁紙と 塗膜を 1 つずつセットで撮影した。次に, 各試料を容器から取り出 して, 色彩計 (コニカミノルタ CM-2600d) で測定径 $8 \mathrm{~mm}$ の円状の 領域（Fig. 6 の赤丸で印す中央部分）を測色した。そして, 測色画 像から同じ $8 \mathrm{~mm}$ の円状の領域に含まれる 23,769 画素の平均 $L^{*} a^{*} b^{*}$ 值を計算した結果と比較した。その結果を Table 4 に示す。

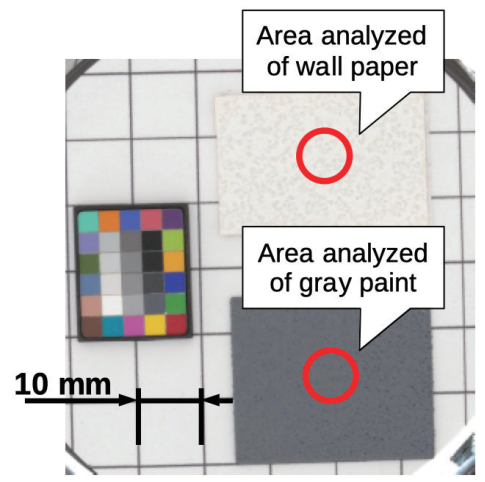

Fig. 6 Example of color-corrected image of condition 3 (concave watch glass)

Table 4 Comparison of measured results of condition 1 (no glass) and condition 3 (concave watch glass) with those of colorimeter

\begin{tabular}{l|rrr|rrr|rr}
\hline Condition & \multicolumn{2}{|c|}{ Proposed method } & \multicolumn{3}{|c|}{ Colorimeter } & \multicolumn{2}{c}{ Color diff. } \\
Samples & $L^{*}$ & $a^{*}$ & $b^{*}$ & $L^{*}$ & $a^{*}$ & $b^{*}$ & $\Delta E^{*} a b$ & Ave. \\
\hline Con1: No glass \\
\hline Wall paper 1 & 93.7 & 0.1 & 2.1 & 93.9 & -0.5 & 3.7 & 1.8 & \\
Wall paper 2 & 93.5 & 0.0 & 2.0 & 94.0 & -0.5 & 3.6 & 1.8 & 1.7 \\
Wall paper 3 & 93.3 & 0.0 & 2.2 & 93.8 & -0.5 & 3.5 & 1.5 & \\
\hline Gray paint 1 & 45.7 & -0.2 & -2.4 & 47.8 & -1.1 & -4.0 & 2.7 & \\
Gray paint 2 & 44.7 & 0.6 & -4.0 & 46.2 & -1.0 & -4.0 & 2.3 & 2.5 \\
Gray paint 3 & 45.4 & 0.1 & -3.1 & 47.2 & -1.0 & -4.0 & 2.4 & \\
\hline Con3: Concave watch glass & \multicolumn{7}{|c}{} \\
\hline Wall paper 1 & 93.8 & -0.1 & 2.1 & 93.9 & -0.5 & 3.7 & 1.7 & \\
Wall paper 2 & 93.6 & 0.0 & 2.0 & 94.0 & -0.5 & 3.6 & 1.7 & 1.7 \\
Wall paper 3 & 93.7 & 0.0 & 2.0 & 93.8 & -0.5 & 3.5 & 1.7 & \\
\hline Gray paint 1 & 45.5 & 0.4 & -2.8 & 47.8 & -1.1 & -4.0 & 3.0 & \\
Gray paint 2 & 44.4 & 0.5 & -3.8 & 46.2 & -1.0 & -4.0 & 2.4 & 2.7 \\
Gray paint 3 & 45.1 & 0.5 & -3.3 & 47.2 & -1.0 & -4.0 & 2.7 & \\
\hline
\end{tabular}


Table 4 より, 条件 1 (開放条件) と色彩計との色差は, 壁紙 3 片の平均で 1.7 , 塗膜 3 片の平均で 2.5 であった。条件 3 (回状ガラ ス閉鎖条件）と色彩計との色差は, 壁紙 3 片の平均で 1.7 , 塗膜 3 片の平均で 2.7 であった。以上のことから, 本研究で提案する測色 法は, 市販の色彩計とも良い一致を示した。

\section{6. まとめ}

本研究では, 閉鎖空間内の材料をその外側から非接触で測色する 方法を示した。空間を隔てるガラスを凹状にし, 受光器をその凹状 ガラス面の焦点に配置することで, 拡散入射／垂直受光の条件での 測色を可能とする。測色精度は, 標準色票に含まれる 24 色に対して 平均色差 0.9 , 最大色差 2.3 であった。これは, ガラスを隔てない 通常の測色 (平均色差 0.7 , 最大色差 1.3) には及ばないものの, 視 感測色 ${ }^{13,14)}$ に比べると高精度での機器測色が可能である。

\section{注}

注1） 本実験で使用したガラス器具類は, 化学実験用として一般に市販され ている製品の中から, Fig. 3 の光学シミュレーションで仮定した寸法 に近いものを選んだ。ただし, 曲率半径は, 時計皿本来の機能と関係 がないこともあり，製品仕様書には記載されていなかった。よって, 曲率半径を指定して入手することは難しく, 異なる曲率半径の凹状ガ ラスを使用する場合は, その焦点位置に, 受光器を設置する必要があ る。

注2）色補正用色票としてはX-Rite 社の ColorChecker が広く使われている が, ColorGauge Nano は Image Science 社のブランドで販売されてい る ColorChecker の小型版 $(17.5 \mathrm{~mm} \times 20.7 \mathrm{~mm})$ である。なお, ColorGauge には無彩色 6 色が追加収録されているが, 本研究では追加 分は使用せず ColorChecker に相当する 24 色のみを利用した。

\section{参考文献}

1）川村政史, 笠井芳夫：ソイルセメントコンクリート製造のための土の見 掛けの表乾状態試験方法に関する実験研究, コンクリート工学論文集, 第 7 巻, 第 1 号, pp. 103-112，1996. 1

2）鈴木卓治：「デジタルアーカイブ」とは何か, 日本色彩学会誌, 第 31 巻, 第 4 号, pp. 280-285，2007. 12

3）日本産業規格：JIS Z8722：2009 色の測定方法-反射及び透過物体色, 2009. 3

4）酒井英樹：色を測る：色彩研究における科学的手法(10) 食品の色を測る, 日本色彩学会誌，第 39 巻，第 6 号，pp. 239-245, 2015.11

5) Nakamori, Y., Iyota, H., Sakai, H., Matsumoto, T., Nomura, S. : Color Monitoring Method under High Temperature during Oven Cooking, Proc. of AIC2015 (Midterm Meeting of the International Colour Association), pp. 856-860, 2015.5

6) OpticalRayTracer Ver.9.6, https://arachnoid. com/OpticalRayTracer/ (Accessed 2020-10-28)

7) Isomi, M., Sakai, H., Watanabe, T. : MEASUREMENT OF WET COLOR CHANGE OF BRICKS DURING DRYING, Journal of Structural and Construction Engineering (Transactions of AIJ), Vol.85, No.777, pp.1367-1373, 2020.11 (in Japanese)

磯見麻衣, 酒井英樹, 渡部嗣道: 濡れレンガの乾燥過程における色調変 化の測定, 日本建築学会構造系論文集, 第 85 巻, 第 777 号, pp. 1367-1373, 2020. 11

8) Orava, J., Jaaskelainen, T., Parkkinen, J. : Color errors of digital cameras, Color research and application, Vol.29, No. 3, pp. 217-221, 2004. 6

9）浦野祐嗣, 小峯秀雄, 安原一哉, 村上哲：デジタルカメラを用いた新し い色彩測定方法と建築材料用石材の色彩評価指標值の提案, 土木学会論 文集 C, 第 62 巻, 第 4 号, pp. 793-802，2006. 12
10) 伊與田浩志, 酒井英樹, 高砂裕行, 島田秀弥: デジタルカメラを用いた 食品の焼き色評価装置の開発, 日本食品工学会誌, 第 11 巻, 第 4 号, pp. 203-213，2010. 12

11）日本産業規格：JIS X9204：2004 高精細カラーディジタル標準画像 (XYZ/SCID) , 2004. 12

12) 日本産業規格：JIS Z8781-4：2013 測色一第 4 部：CIE1976L $L^{*} a^{*} b^{*}$ 色空間, 2013. 12

13) 日本色彩研究所編：色彩ワンポイント 2 色彩管理の基䃈，日本規格協会， pp. 78-79, 1993

14) 小松原仁：色を測る：色彩研究における科学的手法 (5) 視感測色の実際, 日本色彩学会誌，第 39 巻，第 1 号，pp. 30-34，2015.1

[2021 年 2 月 2 日原稿受理 2021 年 4 月 5 日採用決定 $]$ 